\title{
Use of Android Applications towards Small and Medium Enterprise Operations
}

\author{
M F Timara ${ }^{1}$ and Y A Ekawardhani ${ }^{2}$ \\ $\left\{\underline{\text { muhammadfirmantimara@mahasiswa.unikom.ac.id }}^{1}\right.$, $\underline{\text { ekawardani@email.unikom.ac.id }}^{2}$ \} \\ Department of Accounting, Universitas Komputer Indonesia, Indonesia ${ }^{1}$ \\ Department of Visual Communication Design, Universitas Komputer Indonesia, Indonesia ${ }^{2}$
}

\begin{abstract}
The purpose of this study is to make small and medium enterprises can use Android applications to make a process of transactions with consumers easier. Qualitative method used to fulfill this study. The use of experimental methods solely to obtain information directly from consumers. This experience became the main data for this study. The results of this study are that with the Android application system, it will help small and medium businesses to use financial payment systems online that can be reached by every consumer. The conclusion is to find out how consumers regain the experience of using android applications. Since there are problems occur for both financial management and transactions with consumers, this application can simplify the process.
\end{abstract}

Keywords: android application, small and medium enterprise, application

\section{Introduction}

Nowadays, information technology had a positive influence on humans in their daily lives. The existence of mobile devices such as Android has become a major human need. The use of applications in communities has become a habit. In line with the rapid development of technology in mobile phones, there is a change in behavior related to its use. Not only being a calling tool for communication, nowadays it can also be used for transactions. This use is not only intended for consumers but also producers or sellers of goods/services. The initial use of cellphones was limited to the area of communication, but the emergence of an Android-based operating system turned this device into more than just communication. These things can be seen with many users of mobile devices, which can help assignments and tasks in everyday life. With this, the use of mobile devices such as smartphones cannot be stopped wherever and whenever. Using the information technology system has many functions within an organization including automatic processes and key roles to empower technology [1]. The role given by the application of information technology is to help us get information for everyday life [2]. Current technological developments make small and medium enterprises have to be able to keep up with changing situations. Small and medium enterprises are small business entities established by communities that have contributed greatly to state revenues and can reduce unemployment in Indonesia [3].

The android must be able to be used by small and medium enterprises with technology to develop their business. Also, small and medium enterprises must be able to adopt renewable information technology through the Android application system as a modern payment tool to consumers. The internet is one way to market products [4]. Basically, with a payment system 
through an Android-based system, small and medium enterprises must be able to take advantage of transactions with consumers in their daily lives [5]. A small and medium enterprise should be able to keep up with technological changes to support operations by leaving the traditional system towards a user system without cash in use - banknotes as a transaction tool [6].

Bank Negara Indonesia (BNI) as one of the largest government banks, is keen to capture behavioral changes that occur in the community. Nowadays, people are faced with the choice to make conventional or online transactions. Not only for the consumer but for vendor as well. This make vendor can easily attend transaction with the help of apps system.

\section{Method}

The descriptive method is the choice used in this study; the method used is the basis of this research using one example application system that will be displayed in the discussion. The use of descriptive and experimental methods is solely to obtain information directly from consumers. This experience is the main data for this study. The conclusion is to find out how consumers regain the experience of using android applications. Since there are problems that occur for both financial management and transactions with consumers, this application can simplify the process.

\section{Result and Discussion}

To increase competitiveness with small and medium enterprises to support operations with Android applications as one way to utilize information technology today. One of the main functions of operations is to give more efficient system to transact with consumers [7]. With this function in the operation of small and medium enterprises by giving an android application namely Yap Merchant to facilitate small businesses and transact with consumers is.

Yap merchants are facilities from Bank Negara Indonesia for digital payment applications through the Android application that can be accessed using iOS and Android-based operating systems. This Yap merchant reduces the hassles caused by conventional transactions, as well as possible services by using simple and mobile services. Source of funds from BNI credit cards (unikQu) as in below this (Figure 1) shows the main view 

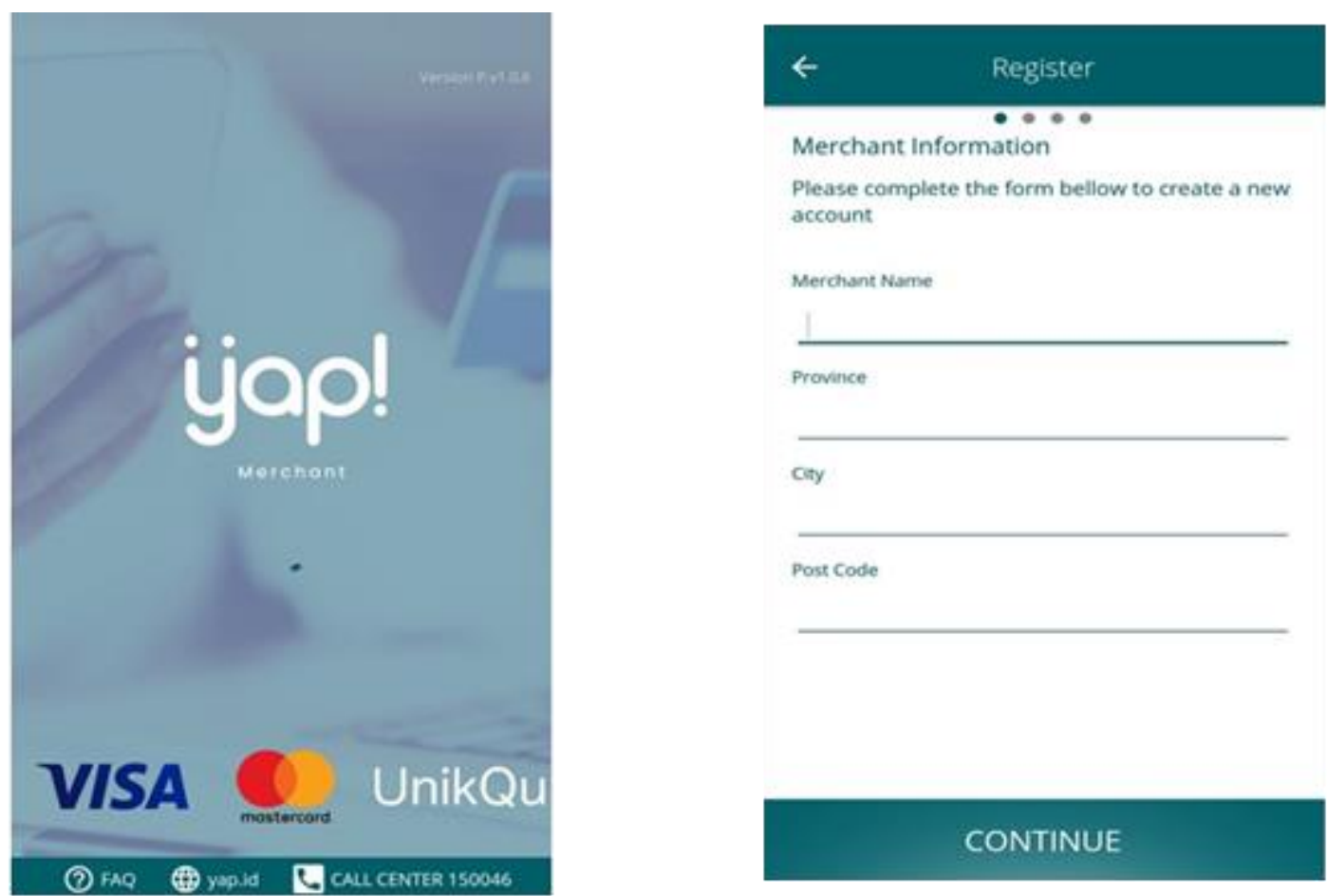

Fig 1. Main View and Registration.

In using the merchant application, the small and medium enterprises must be able to adopt new ideas and innovations from information technology to facilitate operations. This application works for two types of users, namely consumers and vendors. Specifically for vendors this apps reduces the complexity of the conventional buying and selling process, especially in terms of recording and receiving money. Transactions that occur do not involve cash but go directly to the vendor's account. With users without money to facilitate transactions with consumers and make it easier for operations, especially small and medium enterprises, they must go through several stages of use in the use of technology without money [8]. In this case, know how to use it. To be able to enjoy the merchant's facilities, new users need to do the following:

i. Download applications from merchants available at the PlayStore or Appstore

ii. To become a merchant member as follows :

1. Open the application Yap merchant in the PlayStore or Appstore

2. Choose to register with Yap merchants.

3. Read the applicable terms and conditions in the merchant's application users, after understanding the contents with the checkmark (v).

4. Select the default language.

5. Enter business entity data in the registration section.

6. Enter detailed bank information data in the registration section.

7. To get the registration authentication code that is done, you will be asked to input a 6 digit PIN. Create a user ID that you will use every time you log in to the merchant application. The User ID is an email address. Make sure you have registered a valid and active email as a user ID. 
8. Besides the user ID, you will be asked to make mPIN. mPIN is a 4 digit code in the form of numbers needed to $\log$ in to the merchant application every time.

9. After creating a user ID and 4 digit pin, you will receive an SMS sent to the mobile number registered in the BNI system, containing 4 digits of One Time Password (OTP) that must be entered into the application of the merchant as registration validation.

10. Enter the OTP code received from the SMS.

11. If all inputs have been entered. That can use the merchant application as seen in Figure. 2 above

After knowing how to use the application, the merchant can discover how to maintain their business using this app. In this analysis, the benefits of using an android application for small and medium enterprises will be clearly explained. By utilizing payments through cell phones, it is used as a communication tool to replace the exchange of goods and services [9]. In utilizing this technology, it must be able to replace the use of cash as a source of electronic payment instruments for consumers and the public [10]. Apart from being an electronic payment instrument, it can also be an operational financial reporting tool in small and medium enterprises and as a product marketing tool. In this case, you want to know how to use the restrictions on transactions. (Figure 2) shows transaction reports.

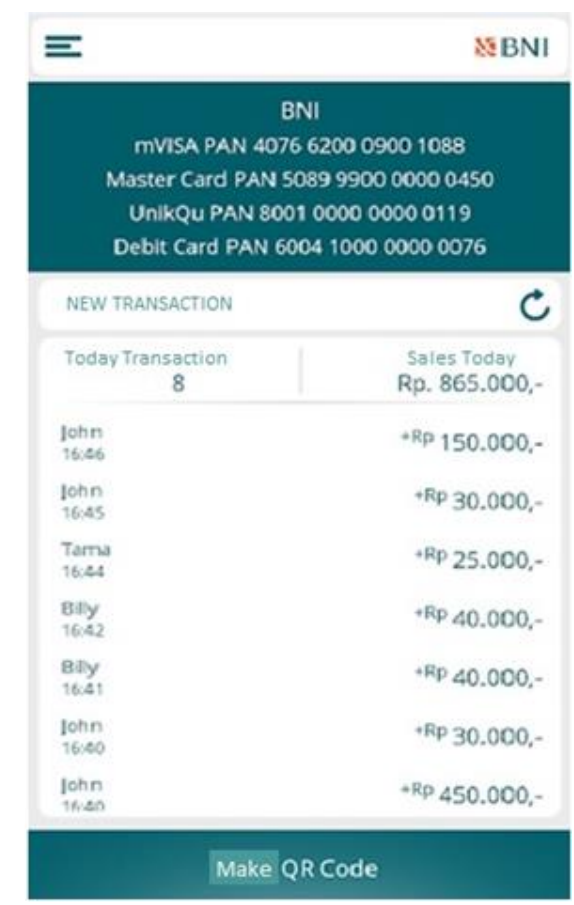

Fig 2. Transaction report.

Yap Merchant facilities can be used by BNI customers for BNI Credit Cardholders and BNI Debit Cards. In restrictions on transactions through yap merchants, Rp 20 million /day/card and according to their BNI credit card limits. As seen in the description in Figure 3, payment from consumers is displayed on the cellphone screen, including the amount and time of transaction. 
In this case, vendors can monitor the impact of profits and losses in transacting with consumers. The application can protect vendors from common mistakes, such as wrong or even forgot to input the transaction in bookkeeping, taking a long time to select products that are of interest to consumers, or knowing which of potential consumers. (Figure 3) shows a scan barcode.

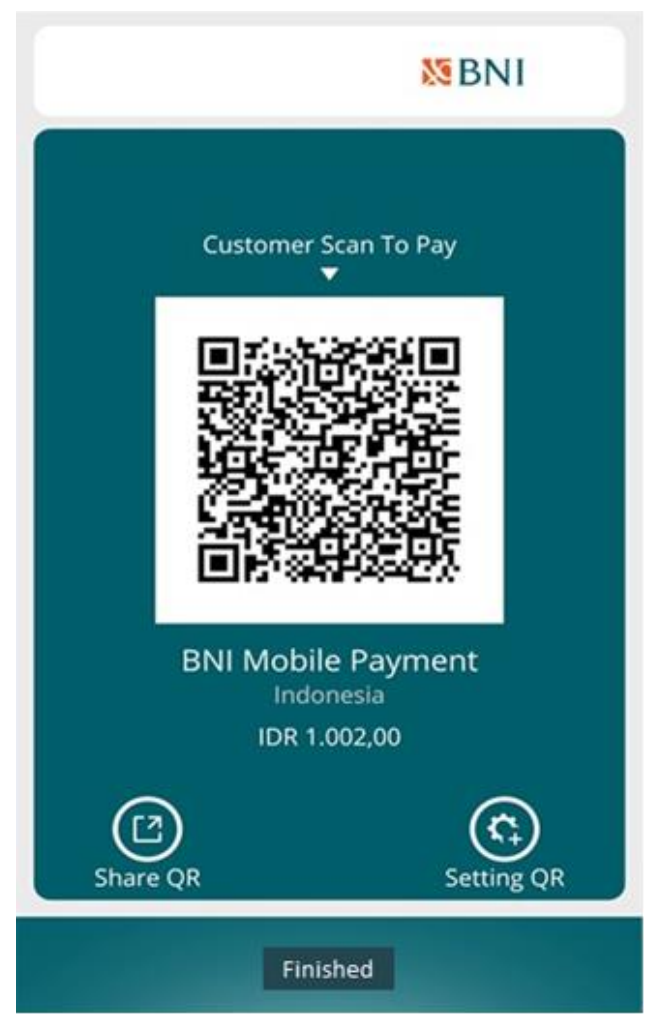

Fig 3. Scan Barcode

In conducting merchant transactions. After registering the source of funds. The impact of the benefits is that the source of funds that can be registered is from the BNI Savings Account, BNI Credit Card, and UnikQu and the impact of loss in dealing with merchants who can be caused by the following:

a. With the provisions that apply to conventional or manual transactions (transactions at EDC merchant machines), there are several card conditions that cause the card cannot be used for transactions such as the card has not been activated, the card has not paid the bill so it cannot use the application.

b. 6 digit PIN by inappropriate application users.

c. Bad network conditions.

d. The internet package from the user has run out.

e. The merchant's QR at the place of the transaction is invalid.

This apps can provide an easy process, especially in transacting and recording the buying and selling process. It is important for vendors to understand how to use it so that it is not left behind in this industrial revolution 4.0. 


\section{Conclusion}

The stages of using this application are important to be understood by the seller, so there is no failure in the transaction process. As explained earlier, that in running this application there are several points that can cause failure. This needs special attention, especially for vendors who will migrate the transaction process from conventional to using Yap merchant apps.

\section{References}

[1] Akinola, O. S.: Cashless society, problems and prospects, data mining research potentials. International Journal of Computer Science and Telecommunications, 3.8, 49-55. (2012).

[2] Amelia, M. N., Prasetyo, Y. E., \& Maharani, I.: E-umkm: Aplikasi Pemasaran Produk UMKM Berbasis Android Sebagai Strategi Meningkatkan Perekonomian Indonesia. Prosiding SNATIF, 1, 11-16. (2017).

[3] Bátiz-Lazo, B., Haigh, T., \& Stearns, D. L.: How the future shaped the past: The case of the cashless society. Enterprise \& Society, 15.1, 103-131. (2014).

[4] Fenuga, O. J., \& Oladejo, R. K.: The effect of electronic payment on customer service delivery in Nigerian banks. International Journal of Economic Development Research and Investment, 1.1, 227-239. (2010).

[5] Garcia-Swartz, D., Hahn, R. W., \& Layne-Farrar, A.: Further thoughts on the cashless society: A reply to Dr. Shampine. Review of Network Economics, 6.4. (2007).

[6] Jauhari, J.: Upaya pengembangan usaha kecil dan menengah (UKM) dengan memanfaatkan ecommerce. Jurnal Sistem Informasi, 2.1, 159-16. (2014).

[7] Khan, J., \& Craig-Lees, M.: Cashless transactions: perceptions of money in mobile payments. (2009). [8] Papadopoulos, G.: Electronic Money and the Possibility of a Cashless Society. (2007).

[9] Soegoto, E. S.: Entrepreneurship Menjadi Pebisnis Ulung Edisi Revisi. Elex Media Komputindo. (2014).

[10] Wardiana, W.: Perkembangan Teknologi Informasi di Indonesia. Seminar dan Pameran Teknologi Informasi 2002, Jurusan Teknik Informatika, 9 Juli 2002. (2002). 